\title{
Antimetastatic Efficacy of the Combination of Caffeine and Valproic Acid on an Orthotopic Human Osteosarcoma Cell Line Model in Nude Mice
}

\author{
KENTARO IGARASHI ${ }^{1,2,3}$, KEI KAWAGUCHI ${ }^{1,2}$, TASUKU KIYUNA ${ }^{1,2}$, \\ TAKASHI MURAKAMI ${ }^{1,2}$, NORIO YAMAMOTO ${ }^{3}$, KATSUHIRO HAYASHI $^{3}$, \\ HIROAKI KIMURA $^{3}$, SHINJI MIWA ${ }^{3}$, HIROYUKI TSUCHIYA ${ }^{3}$ and ROBERT M. HOFFMAN ${ }^{1,2}$ \\ ${ }^{1}$ AntiCancer, Inc., San Diego, CA, U.S.A.; \\ ${ }^{2}$ Department of Surgery, University of California, San Diego, CA, U.S.A.; \\ ${ }^{3}$ Department of Orthopaedic Surgery, Kanazawa University, Kanazawa, Japan
}

\begin{abstract}
Aim: We have previously reported that caffeine can enhance chemotherapy efficacy of bone and soft tissue sarcoma via cell-cycle perturbation. Valproic acid has histone deacetylase (HDAC) inhibitory activity. We have also reported the anti-tumor efficacy of combination treatment with caffeine and valproic acid against osteosarcoma primary tumors in a cell-line orthotopic mouse model. Materials and Methods: In this study, we performed combination treatment of caffeine and valproic acid on osteosarcoma cell lines in vitro and in spontaneous and experimental lung metastasis mouse models of osteosarcoma. Survival of 143B-RFP human osteosarcoma cells after exposure to caffeine and valproic acid for 72 hours was determined using the WST-8 assay. $I C_{50}$ values and combination indices were calculated. Mouse models of primary osteosarcoma and spontaneous lung metastasis were obtained by orthotopic intra-tibial injection of 143B-RFP cells. Valproic acid, caffeine, and combination of both drugs were administered from day 7, five times a week, for four weeks. Six weeks after orthotopic injection, lung samples were excised and observed with a fluorescence imaging system. A mouse model of experimental lung metastasis was obtained by tail vein injection of 143B-RFP cells. The mice were treated with these agents from day 0 , five times a week for four weeks. Results: Both caffeine and
\end{abstract}

Correspondence to: Robert M. Hoffman, Ph.D., AntiCancer, Inc., 7917 Ostrow Street, San Diego, CA 92111, U.S.A. Tel: +1 8586542555, Fax: +18582684175, e-mail: all@anticancer.com or Hiroyuki Tsuchiya, MD, Ph.D., Department of Orthopaedic Surgery, Kanazawa University, Kanazawa, Japan. Tel: +81 762652374, Fax: +81 762344261, e-mail: tsuchi@med.kanazawa-u.ac.jp

Key Words: Osteosarcoma, 143B, red fluorescent protein, RFP, orthotopic, nude mice, caffeine, valproic acid, combination therapy. valproic acid caused concentration-dependent cell kill in vitro. Synergistic efficacy of the combination treatment was observed. In the spontaneous lung-metastasis model, the number of lung metastasis was $9.0 \pm 2.6$ in the untreated group (G1); 10.8 \pm 2.9 in the caffeine group (G2); $10.0 \pm 3.1$ in the valproic-acid group (G3); and 3.0 \pm 1.1 in the combination group (G4); $(p=6.78 E-5$ control vs. combination; $p=0.006$ valproic acid vs. combination; $p=0.003$ caffeine $v s$. combination). In the experimental lung-metastasis model, the combination group significantly reduced lung metastases and improved overall survival ( $p=0.0005)$. Conclusion: Efficacy of the combination of caffeine and valproic acid was observed in vitro and in spontaneous and experimental lung-metastasis mouse models of osteosarcoma.

Osteosarcoma is a malignant primary bone tumor which occurs mainly in adolescents and young adults (1). Osteosarcoma has a 5-year survival of approximately $70 \%$ (2-4). However, patients with metastatic disease at diagnosis or with recurrent disease have a 5-year survival rate of $20 \%$ (5). The lung is the predominant site of metastasis and the most common cause of death in osteosarcoma patients (6).

First-line therapy against osteosarcoma consists of highdose methotrexate, cisplatin, doxorubicin, and ifosfamide. However, dose-intensive chemotherapy regimens with these drugs have not improved outcomes (7). Therefore, novel systemic therapy is needed to improve the outcome of metastatic osteosarcoma.

Caffeine (1,3,7-trimethylxanthine) (8) can induce apoptosis (9-12), delays in cell cycle progression $(13,14)$ and can enhance the toxicity of radiation and anti-cancer agents (1517). Modulation of the cell cycle by caffeine can be imaged in cancer cells expressing a fluorescent ubiquitination-based cell cycle indicator (FUCCI). Caffeine overcame cisplatinum (CDDP) cell-cycle arrest, thereby increasing CDDP efficacy 
$(18,19)$. We have previously reported that caffeine-combined chemotherapy improved the treatment of bone and soft tissue sarcoma cases in the clinic (20-22).

Valproic acid, a short chain fatty acid, is a histonedeacetylase (HDAC) inhibitor. Combination chemotherapy including valproate has been tested in myelodysplastic syndrome (23), melanoma (24), and solid tumors (25).

We have previously reported the efficacy of combination treatment of caffeine and valproic acid against a localizedosteosarcoma orthotopic-mouse model (18). In the present study, we determined the efficacy of the combination of caffeine and valproic acid on spontaneous and experimental metastasis in nude mouse models of a human osteosarcoma cell line.

\section{Materials and Methods}

Drugs. Valproic acid and caffeine were obtained from Wako Pure Chemical Industries, Ltd. (Osaka, Japan).

Cell line and growth conditions. 143B-RFP osteosarcoma cells were generated as previously described (26). All cells were grown in RPMI 1640 medium (Gibco, Grand Island, NY, USA) supplemented with $10 \%$ fetal bovine serum, $100 \mathrm{U} / \mathrm{ml}$ penicillin, and $100 \mu \mathrm{g} / \mathrm{ml}$ streptomycin. Cells were maintained in $\log$ phase by supplementation with fresh medium 2-3 times/week.

In vitro cell inhibition assay. Cellular viability was assessed using the WST-8 dye (2-(2-methoxy-4-nitrophenyl)-3-(4-nitrophenyl)-5(2,4-disulfophenyl)-2H-tetrazolium) assay (Dojindo, Kumamoto, Japan). Briefly, cells were seeded in 96-well flat-bottomed microplates $\left(5 \times 10^{4}\right.$ cells $\left./ \mathrm{ml}\right)$, incubated at $37^{\circ} \mathrm{C}$ for $24 \mathrm{~h}$, and exposed to various concentrations of tested compounds for $72 \mathrm{~h}$. For each concentration, at least 8 wells were used. After incubation with the test compounds, $10 \mu \mathrm{l}$ WST- 8 solution was added to each well. The microplates were further incubated for $3 \mathrm{~h}$ at $37^{\circ} \mathrm{C}$, and absorption was measured using a microprocessor-controlled microplate reader (Sunrise ${ }^{\mathrm{TM}}$; TECAN, San Jose, CA, USA) at 450 $\mathrm{nm}$. The cell-survival fraction was calculated as the percentage of untreated control cells, and $\mathrm{IC}_{50}$ values were derived.

Calculation of Combination Index (CI). The specific interaction between caffeine and valproic acid on osteosarcoma cell lines was evaluated with the combination index (CI) assay using the CalcuSyn software from ComboSyn Inc. (New Jersey, USA), (Chou and Talalay (27)). Synergy is defined as a CI $<1.0$; antagonism as a CI $>1.0$; and additivity as CI values not significantly different from 1.0.

Mice. Athymic nu/nu nude mice (AntiCancer Inc., San Diego, CA), 4-6 weeks old, were used in this study. The animals were fed an autoclaved laboratory rodent diet. Animals were housed in a barrier facility on a high-efficiency particulate arrestance (HEPA)filtered rack under standard conditions of 12-hour light/dark cycles. All animal studies were conducted in accordance with the principles and procedures outlined in the National Institutes of Health Guide for the Care and Use of Animals under Assurance Number A3873-1. In order to minimize any suffering of the animals, the use of anesthesia and analgesics were used for all surgical experiments. Animals were anesthetized by subcutaneous injection of a $0.02 \mathrm{ml}$ solution of $20 \mathrm{mg} / \mathrm{kg}$ ketamine, $15.2 \mathrm{mg} / \mathrm{kg}$ xylazine, and $0.48 \mathrm{mg} / \mathrm{kg}$ acepromazine maleate.

Orthotopic spontaneous lung-metastasis model. Four- to six-week-old nude mice were anesthetized by the ketamine mixture via s.c. injection. The leg was sterilized with alcohol and an approximately 2-mm midline skin incision was made just below the knee joint to expose the tibial tuberosity. 143B-RFP cells $\left(2 \times 10^{5}\right)$ in Matrigel $(5 \mu \mathrm{l})$ (BD Bioscience, San Jose, CA, USA) were injected per mouse into the intramedullary cavity of the left tibia with a latex-free insulin syringe $(0.5-\mathrm{ml} 31 \mathrm{G})$ (TYCO Health Group LP, Mansfield, MA, USA). The skin was closed with a 6-0 suture.

Experimental lung metastasis model of osteosarcoma. Four- to sixweek-old nude mice were used. 143B-RFP cells $\left(2 \times 10^{6}\right.$ cells in 100 $\mu \mathrm{l}$ PBS) were injected into the tail vein of 24 nude mice (day 0 ).

Treatment design. For the experimental metastasis model, on day 0 of tail-vein cell injection, mice were randomized into 2 groups; G1: control without treatment $(n=12) ; \mathrm{G} 2$ : treated with the combination of caffeine $(100 \mathrm{mg} / \mathrm{kg})$ and valproic acid $(500 \mathrm{mg} / \mathrm{kg})$ by i.p. injection five times a week for 4 weeks $(n=12)$. On day 28, eight mice (4 mice each group) were sacrificed and the lungs were imaged to observe RFP-expressing lung metastases and to determine the efficacy of therapy. The fluorescent areas of the lung metastasis were recorded using the OV100 variable magnification small animal imaging system (Olympus, Tokyo, Japan) (28). An additional 16 mice comprising 8 control mice, 8 caffeine-combined-with-valproicacid-treated mice were observed for survival analysis.

For the spontaneous-metastasis model, one week after orthotopic implantation, mice were randomized into 4 groups; G1: control without treatment $(\mathrm{n}=8)$; $\mathrm{G} 2$ : treated with caffeine $(100 \mathrm{mg} / \mathrm{kg})$, i.p., five times a week for 4 weeks $(n=8)$; G3: treated with valproic acid $(500 \mathrm{mg} / \mathrm{kg})$, i.p., five times a week for 4 weeks $(\mathrm{n}=8) ; \mathrm{G} 4$ : treated with the combination of caffeine $(100 \mathrm{mg} / \mathrm{kg})$; and valproic acid $(500 \mathrm{mg} / \mathrm{kg})$, i.p., five times a week for 4 weeks $(\mathrm{n}=8)$. Tumor length, width, and mouse body weight were measured once in a week. Six weeks after implantation, all mice were sacrificed. The lungs were excised and the metastases on the surface were imaged and counted with the OV100.

Primary tumor-growth determination. Tumor volumes were calculated using the following equation: volume $=4 \pi$ $(\mathrm{A} / 2)(\mathrm{B} / 2)(\mathrm{C} / 2) / 3$, where $\mathrm{A}$ is the width (average distance in the medial-lateral plane), $\mathrm{B}$ is the length (average distance in the proximal-distal plane), and $\mathrm{C}$ is the width (average distance in the anterior-posterior plane). Data are presented as mean $\pm \mathrm{SD}$.

\section{Results and Discussion}

Cell killing by caffeine and valproic acid. The cell-kill activity of caffeine and valproic acid was determined on the 143B-RFP osteosarcoma cell line. Each compound significantly inhibited 143B-RFP cell growth in a dosedependent manner (Figure 1). Addition of 50 and $100 \mu \mathrm{g} / \mathrm{ml}$ valproic acid to caffeine enhanced the cell kill of 143B-RFP cells (Figure 1, Table I). In addition, the CI values were significantly $<1$ and thereby demonstrated synergy at almost all tested concentrations on 143B-RFP cells (Table II). 

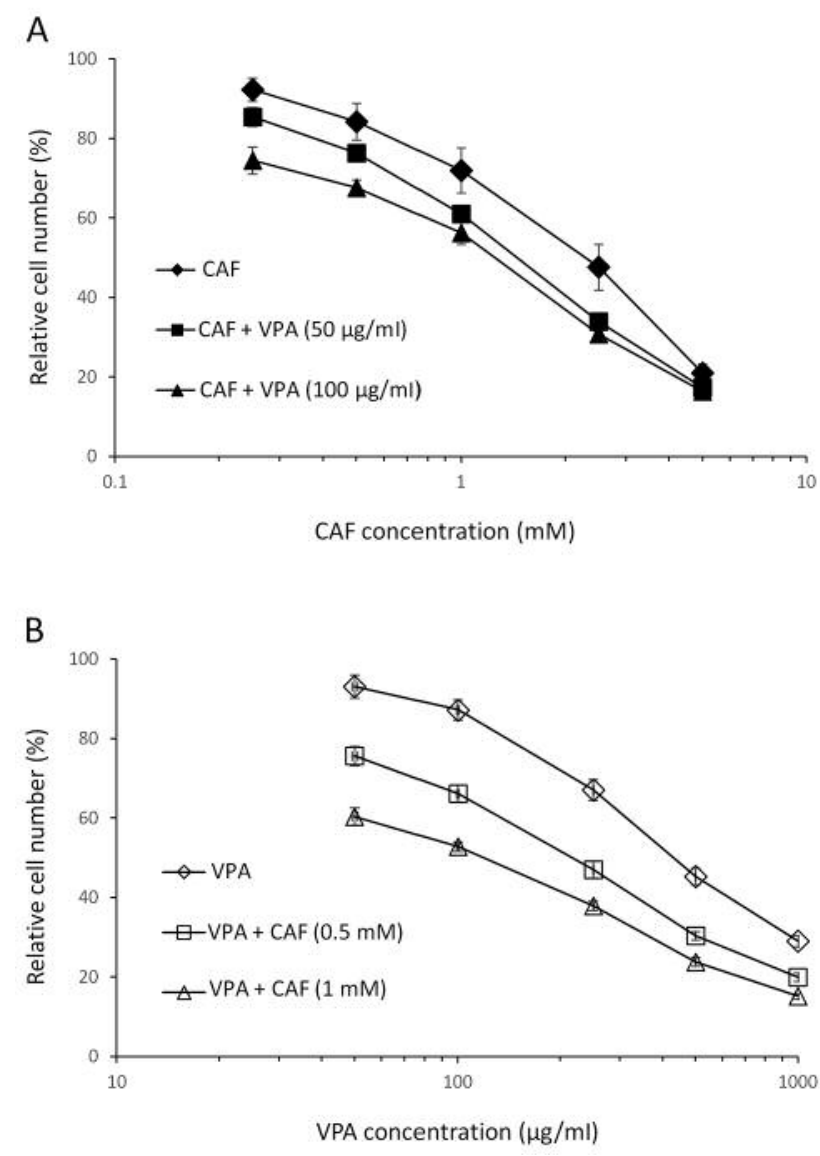

Figure 1. Growth inhibition assay of caffeine (CAF) and valproic acid (VPA) against 143B-RFP cells. Osteosarcoma cells were incubated with each drug for 72 hrs and then counted with the WST-8 assay. (A) Efficacy of VPA as a function of CAF concentration. (B) Efficacy of $C A F$ as a function of VPA concentration.

Table I. IC 50 value of caffeine (CAF) on 143B-RFP cells with and without valproic acid (VPA).

\begin{tabular}{|c|c|c|c|}
\hline \multicolumn{4}{|c|}{$\mathrm{CAF} \mathrm{IC}_{50}(\mathrm{mM})$} \\
\hline & & +VPA $50 \mu \mathrm{g} / \mathrm{ml}$ & +VPA $100 \mu \mathrm{g} / \mathrm{ml}$ \\
\hline 143B-RFP & $2.02 \pm 0.29$ & $1.47 \pm 0.10 * *$ & $1.14 \pm 0.09 * *$ \\
\hline
\end{tabular}

143B-RFP cells were incubated with each drug for $72 \mathrm{hrs}$ and then counted with the WST- 8 assay.

Efficacy of caffeine and valproic acid on primary osteosarcoma and spontaneous lung metastases in the orthotopic model. The volume of the primary tumor was $5085.1 \pm 1183 \mathrm{~mm}^{3}$ in the untreated group $(\mathrm{G} 1) ; 3781.8 \pm 1303 \mathrm{~mm}^{3}$ in the caffeine group
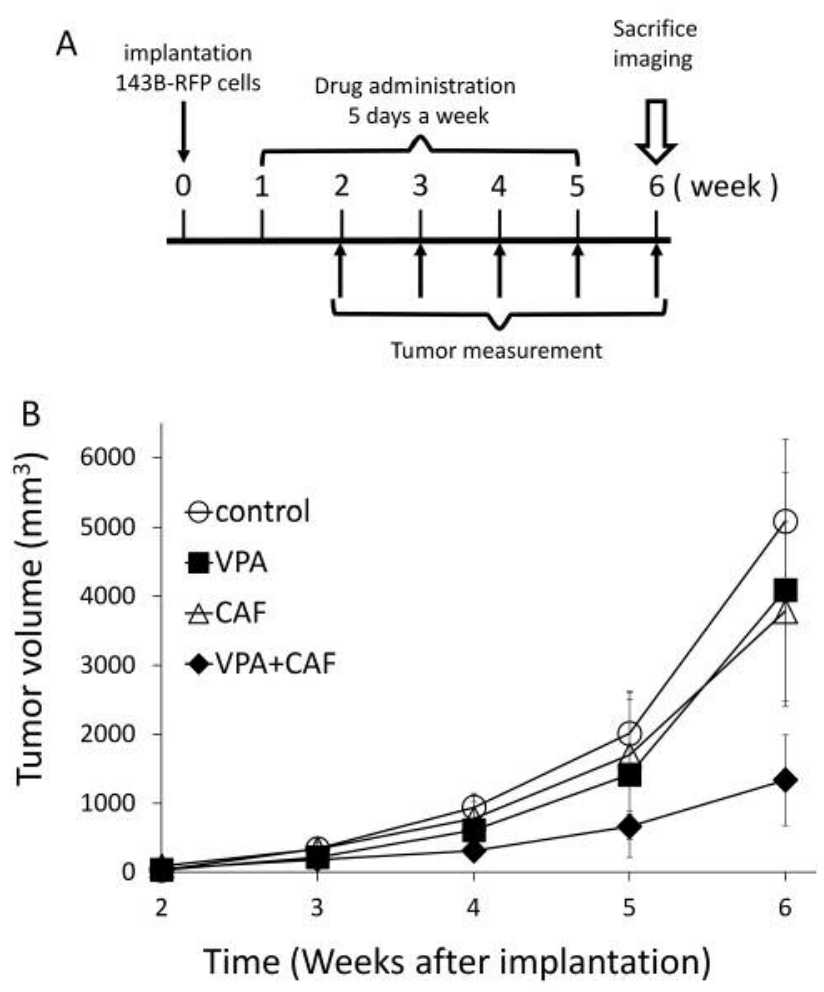

Figure 2. Efficacy determination of caffeine $(C A F)$ and valproic acid (VPA) on an orthotopic mouse model of 143B-RFP osteosarcoma. (A) Treatment scheme of CAF and VPA on the orthotopic model of osteosarcoma. (B) 143B-RFP cells were orthotopically transplanted into the proximal tibia of nude mice and allowed to form tumors. Mice were treated with CAF, VPA, or the combination of CAF and VPA, i.p. CAF (100 $\mathrm{mg} / \mathrm{kg}), V P A(500 \mathrm{mg} / \mathrm{kg})$ five times a week for four weeks. $N=8$ mice/group.

Table II. CI values of the combination of CAF and VPA.

\begin{tabular}{lcccccc}
\hline \multicolumn{2}{c}{ Combination ratio } & & \multicolumn{3}{c}{ Combination ratio } & \\
\cline { 1 - 1 } \cline { 5 - 6 } CAF $(\mathrm{mM})$ & $\begin{array}{c}\mathrm{VPA} \\
(\mu \mathrm{g} / \mathrm{ml})\end{array}$ & CI & CAF $(\mathrm{mM})$ & $\begin{array}{c}\text { VPA } \\
(\mu \mathrm{g} / \mathrm{ml})\end{array}$ & CI \\
\hline 0.25 & 50 & 1.00803 & 0.25 & 100 & 0.83611 \\
0.5 & 50 & 0.93848 & 0.5 & 100 & 0.86373 \\
1 & 50 & 0.88176 & 1 & 100 & 0.88619 \\
2.5 & 50 & 0.79659 & 2.5 & 100 & 0.76623 \\
5 & 50 & 0.73972 & 5 & 100 & 0.73094 \\
\hline
\end{tabular}

CI values of $<1,1$, or $>1$ indicate synergy, additively, and antagonism, respectively.

(G2) $(p=0.09) ; 4088.6 \pm 1687 \mathrm{~mm}^{3}$ in the valproic acid group (G3) $(p=0.584)$; and $1335.3 \pm 657 \mathrm{~mm}^{3}$ in the caffeine and valproic-acid combination group (G4) $(p=0.001)$; (Figure 2b). The number of lung metastasis was $9.0 \pm 2.6$ in the untreated 

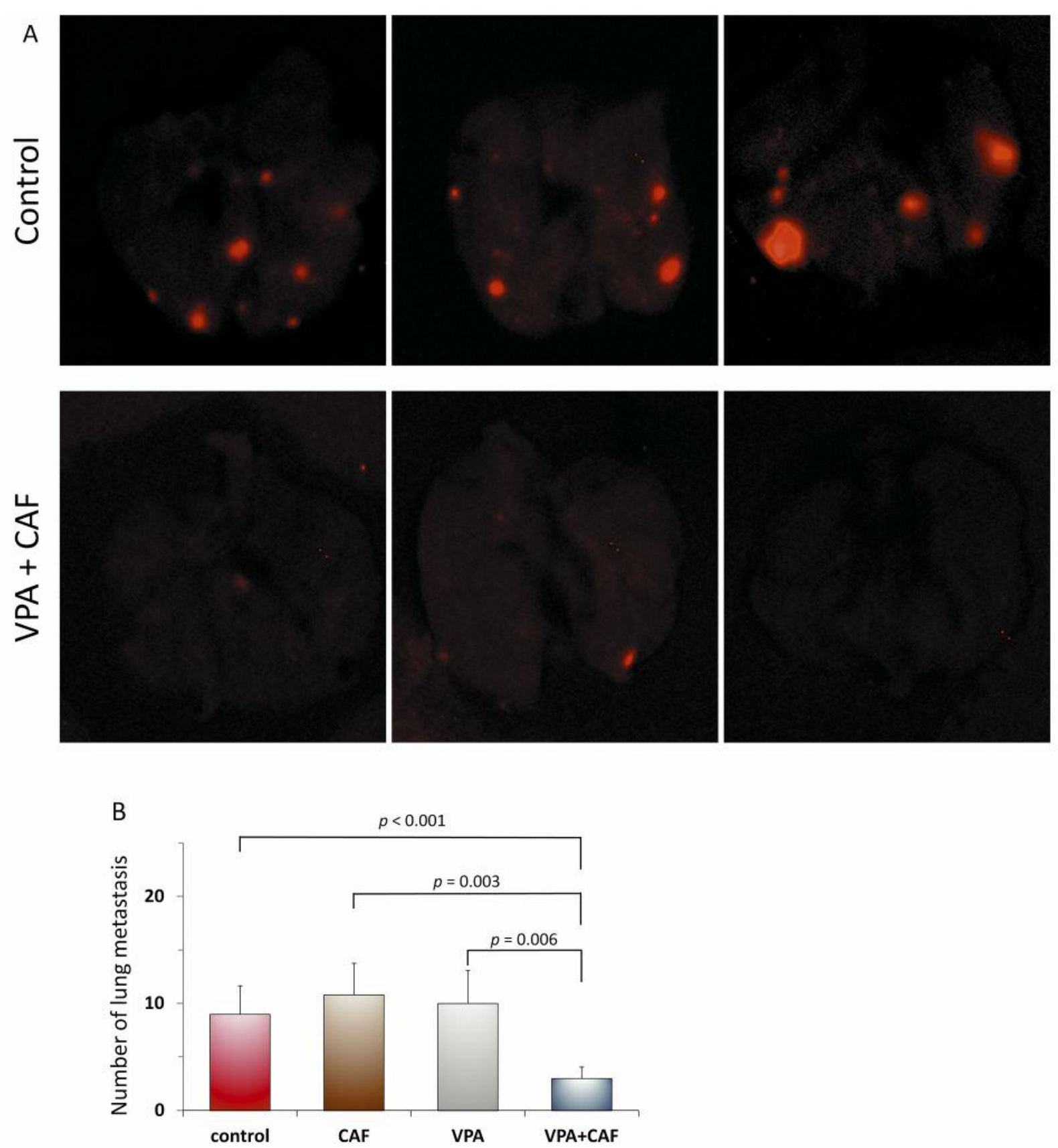

Figure 3. Efficacy of valproic acid (VPA) and caffeine (CAF) on spontaneous lung metastases of 143B-RFP osteosarcoma (31, 32). (A) Fluorescence imaging of spontaneous lung metastases in the control and mice treated with the combination of CAF and VPA. (B) Number of lung metastases in control and mice treated with CAF, VPA or VPA combined with CAF.

group (G1); $10.8 \pm 2.9$ in the caffeine group $(\mathrm{G} 2) ; 10.0 \pm 3.1$ in the valproic acid group $(\mathrm{G} 3)$; and $3.0 \pm 1.1$ in the combination group (G4); $(p=6.78 \mathrm{E}-5$ control vs. combination; $p=0.006$ valproic acid vs. combination; $p=0.003$ caffeine vs. combination); (Figure 3b).
Efficacy of caffeine and valproic acid on osteosarcoma experimental lung metastasis. Fluorescence imaging demonstrated that the combination of caffeine and valproic acid strongly inhibited experimental lung metastases (Figure $4 c)$. The mean fluorescence intensity of lung metastases of the 
A

\section{B-RFP osteosarcoma cells}

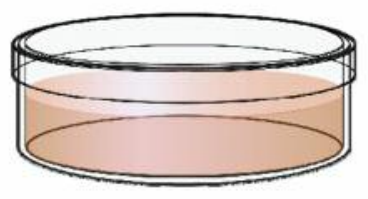

Tail vein injection

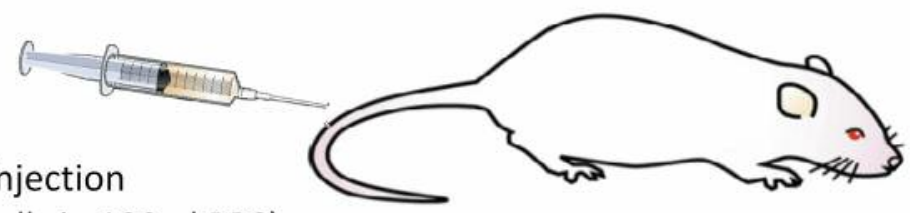

$\left(2 \times 10^{6}\right.$ cells in $\left.100 \mu \mathrm{lPBS}\right)$

B

Drug administration

5 days a week

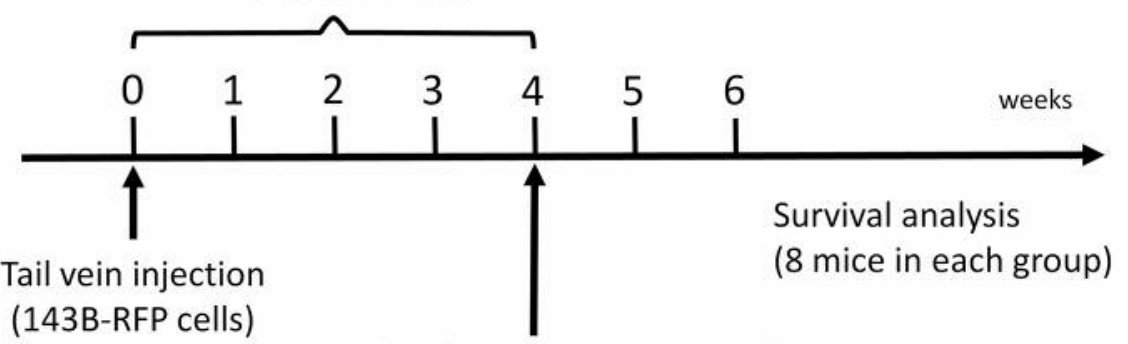

Sacrifice (4 mice in each group)

Evaluation of fluorescent area

\section{C}
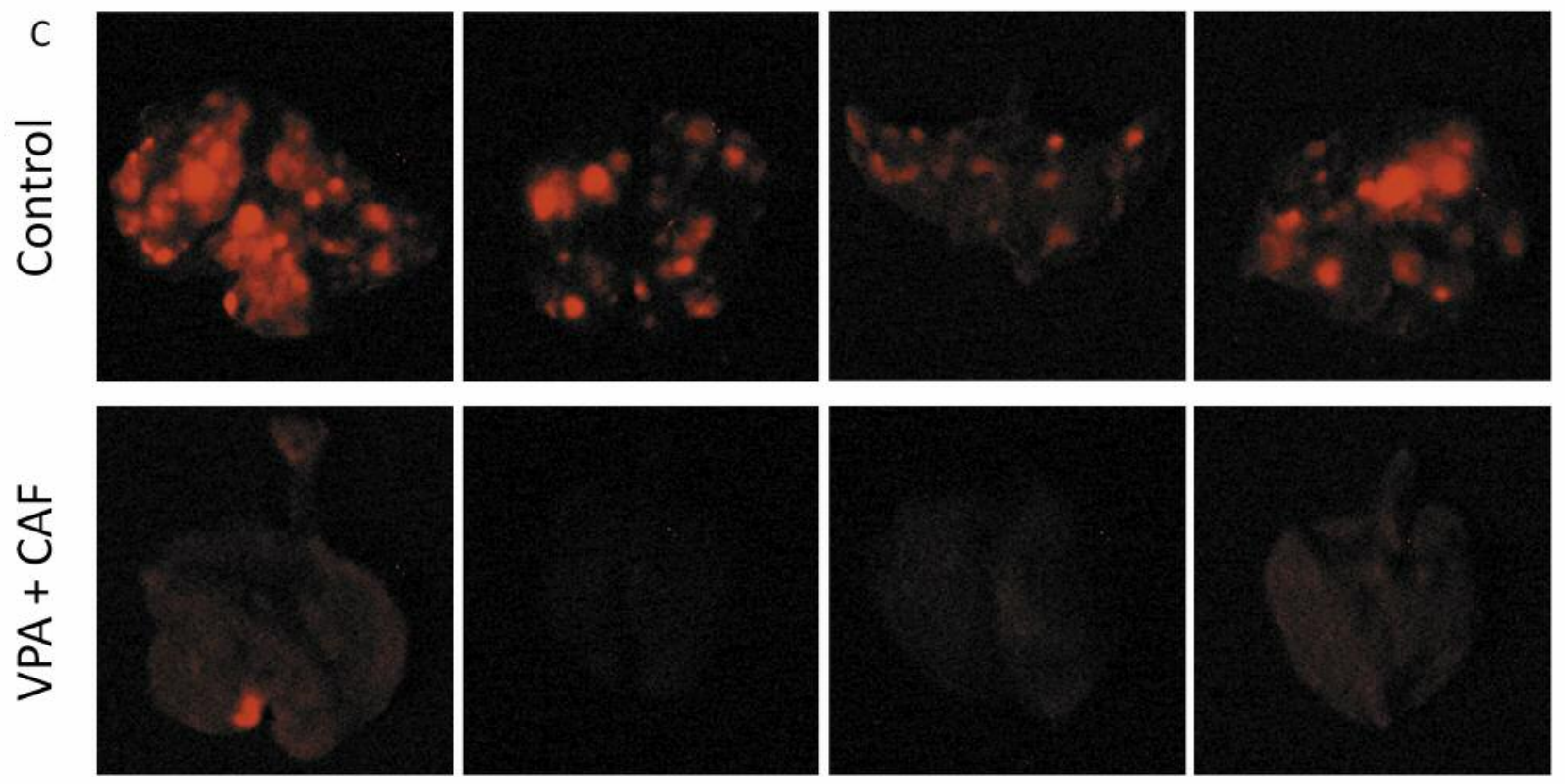

Figure 4. Continued 

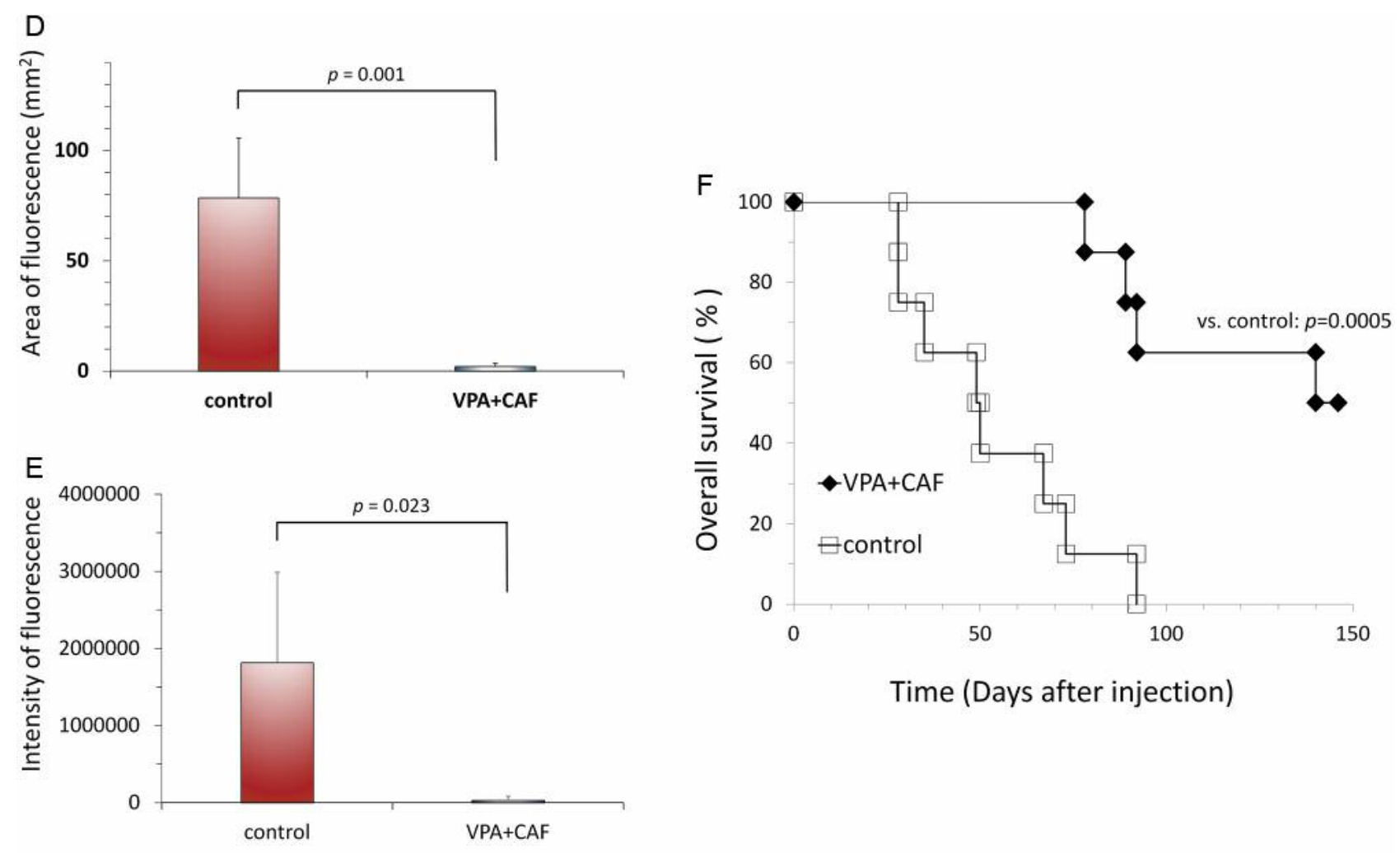

Figure 4. Efficacy of valproic acid (VPA) combined with caffeine (CAF) on experimental lung metastases. (A) Mouse model of osteosarcoma experimental lung metastases. (B) Treatment scheme. (C) Fluorescence imaging of lung metastases with and without VPA+CAF treatment (31, 32). (D) Fluorescence area of osteosarcoma lung metastases with and without VPA+CAF treatment. (E) Fluorescent intensity of $143 B$-RFP osteosarcoma lung metastases with and without VPA+CAF treatment. (F) Kaplan-Meier survival curve of mice with 143B-RFP osteosarcoma treated with $V P A+C A F$ compared to control untreated mice.

control mice was $1.82 \times 10^{6}$ and for the combination of caffeine and valproic acid treated mice was $3.17 \times 10^{4},(p=0.023)$; (Figure $4 \mathrm{~d}$ ). The fluorescent area of the lung metastases of control mice was $78.6 \pm 27.2 \mathrm{~mm}^{2}$ and for the caffeine-valproic acid treated mice was $2.1 \pm 1.6 \mathrm{~mm}^{2},(p=0.001)$; (Figure 4e).

Kaplan-Meier analysis with the log rank test demonstrated that the combination of caffeine and valproic acid significantly improved the survival of the treated mice $(p=0.0005)$; (Figure 4f).

The present study demonstrates the potential of caffeine and valproic acid for effective treatment of osteosarcoma using an established cell line. Future studies will focus on patient-derived orthotopic xenograft (PDOX) models of osteosarcoma $(29,30)$.

\section{References}

1 Mirabello L, Troisi RJ and Savage SA: International osteosarcoma incidence patterns in children and adolescents, middle ages and elderly persons. Int J Cancer 1: 229-234, 2009.
2 Isakoff MS, Bielack SS, Meltzer $\mathrm{P}$ and Gorlick R: Osteosarcoma: Current Treatment and a Collaborative Pathway to Success. J Clin Oncol 33: 3029-3035, 2015.

3 Bacci G, Ferrari S, Lari S, Mercuri M, Donati D, Longhi A, Forni C, Bertoni F, Versari M and Pignotti E: Osteosarcoma of the limb: amputation or limb salvage in patients treated by neoadjuvant chemotherapy. J Bone Joint Surg Br 84: 88-92, 2002.

4 Muscolo DL, Ayerza MA, Aponte-Tinao LA and Ranalletta M: Partial epiphyseal preservation and intercalary allograft reconstruction in high-grade metaphyseal osteosarcoma of the knee. J Bone Joint Surg Am 86: 2686-2693, 2002.

5 Hughes DP: Strategies for the targeted delivery of therapeutics for osteosarcoma. Expert Opin Drug Deliv 6: 1311-1321, 2009.

6 Rasalkar DD, Chu WC, Lee V, Paunipagar BK, Cheng FW and Li CK: Pulmonary metastases in children with osteosarcoma: characteristics and impact on patient survival. Pediatr Radiol 2: 227-236, 2011.

7 Lewis VO: What's new in musculoskeletal oncology. J Bone Joint Surg Am 89: 1399-1407, 2007.

8 IARC working group on the evaluation of carcinogenic risks to humans: Coffee, tea, mate, methylxanthines and methylglyoxal. IARC Monogr Eval Carcinog Risks Hum 51: 1-513, 1991. 
9 Levi-Schaffer F and Touitou E: Xanthines inhibit $3 \mathrm{~T} 3$ fibroblast proliferation. Skin Pharmacol 4: 286-290, 1991.

10 Miwa S, Sugimoto N, Shirai T, Hayashi K, Nishida H, Ohnari I, Takeuchi A, Yachie A and Tsuchiya H: Caffeine activates tumor suppressor PTEN in sarcoma cells Int J Oncol 39: 465-472, 2011

11 Miwa S, Sugimoto N, Yamamoto N, Shirai T, Nishida H, Hayashi K, Kimura H, Takeuchi A, Igarashi K, Yachie A and Tsuchiya $\mathrm{H}$ : Caffeine induces apoptosis of osteosarcoma cells by inhibiting AKT/mTOR/S6K, NF-kB and MAPK pathways. Anticancer Res 32: 3643-3649, 2012.

12 He Z, Ma WY, Hashimoto T, Bode AM, Yang CS and Dong Z: Induction of apoptosis by caffeine is mediated by the p53, Bax, and caspase 3 pathways. Cancer Res 63: 4396-4401, 2003.

13 Tolmach LJ, Jones RW and Busse PM: The action of caffeine on $\mathrm{x}$-irradiated Hela cells. I. Delayedinhibition of DNA synthesis. Radiat Res 71: 653-665, 1977.

14 Lau CC and Pardee AB: Mechanism by which caffeine potentiates lethality of nitrogen mustard. Proc Natl Acad Sci USA 79: 2942-2946, 1982.

15 Tolmach LJ, Jones RW and Busse PM: The action of caffeine on x-irradiated Hela cells. I. Delayed inhibition of DNA synthesis. Radiat Res 71: 653-665, 1977.

16 Busse PM, Bose SK, Jones RW and Tolmach LJ: The action of caffeine on $\mathrm{x}$-irradiated hela cells. Ii. Synergistic lethality. Radiat Res 71: 666-677, 1977.

17 Busse PM, Bose SK, Jones RW and Tolmach LJ: The action of caffeine on $\mathrm{x}$-irradiated hela cells. Iii. Enhancement of x-rayinduced killing during g2 arrest. Radiat Res 76: 292-307, 1978.

18 Igarashi K, Yamamoto N, Hayashi K, Takeuchi A, Kimura H, Miwa S, Hoffman RM and Tsuchiya H: Non-toxic efficacy of the combination of caffeine and valproic acid on human osteosarcoma cells in vitro and in orthotopic nude-mouse models. Anticancer Res 36: 4477-4482, 2016.

19 Miwa S, Yano S, Tome Y, Sugimoto N, Hiroshima Y, Uehara F, Mii S, Kimura H, Hayashi K, Efimova EV, Fujiwara T, Tsuchiya $\mathrm{H}$ and Hoffman RM: Dynamic color-coded fluorescence imaging of the cell-cycle phase, mitosis, and apoptosis demonstrates how caffeine modulates cisplatinum efficacy. J Cell Biochem 114: 2454-2460, 2013.

20 Tsuchiya H, Tomita K, Mori Y, Asada N and Yamamoto N: Marginal excision for osteosarcoma with caffeine assisted chemotherapy. Clin Orthop 358: 27-35, 1999.

21 Tsuchiya H, Yasutake H, Yokogawa A, Baba H, Ueda Y and Tomita K: Effect of chemotherapy combined with caffeine for osteosarcoma. J Cancer Res Clin Oncol 118: 567-569, 1992.

22 Tsuchiya H, Tomita K, Mori Y, Asada N, Morinaga T, Kitano S and Yamamoto $\mathrm{N}$ : Caffeine-assisted chemotherapy and minimized tumor excision for nonmetastatic osteosarcoma. Anticancer Res 18: 657-666, 1998.

23 Raffoux E, Cras A, Recher C, Boëlle PY, de Labarthe A, Turlure P, Marolleau JP, Reman O, Gardin C, Victor M, Maury S, Rousselot P, Malfuson JV, Maarek O, Daniel MT, Fenaux P, Degos L, Chomienne C, Chevret S and Dombret H: Phase 2 clinical trial of 5-azacytidine, valproic acid and all-trans retinoic acid in patients with high-risk acute myeloid leukemia or myelodysplastic syndrome. Oncotarget 1: 34-42, 2010.
24 Rocca A, Minucci S, Tosti G, Croci D, Contegno F, Ballarini M, Nolè F, Munzone E, Salmaggi A, Goldhirsch A, Pelicci PG and Testori A: A phase I-II study of the histone deacetylase inhibitor valproic acid plus chemoimmunotherapy in patients with advanced melanoma. Br J Cancer 100: 28-36, 2009.

25 Munster PN, Marchion D, Bicaku E, Lacevic M, Kim J, Centeno B, Daud A, Neuger A, Minton S and Sullivan D: Clinical and biological effects of valproic acid as a histone deacetylase inhibitor on tumor and surrogate tissues: phase 1/2 trial of valproic acid and epirubicin/FEC. Clin Cancer Res 15: 24882496, 2009.

26 Kimura H, Tome Y, Momiyama M, Hayashi K, Tsuchiya H, Bouvet $M$ and Hoffman RM: Imaging the inhibition by anti- $\beta 1$ integrin antibody of lung seeding of single osteosarcoma cells in live mice. Int J Cancer 131: 2027-2033, 2012.

27 Chou TC and Martin N: CompuSyn for Drug Combinations: PC Software and User's Guide: A Computer Program for Quantitation of Synergism and Antagonism in Drug Combinations, and the Determination of $\mathrm{IC}_{50}$ and $\mathrm{ED}_{50}$ and $\mathrm{LD}_{50}$ Values. ComboSyn Inc, Paramus, NJ, USA, 2005.

28 Yamauchi K, Yang M, Jiang P, Xu M, Yamamoto N, Tsuchiya H, Tomita K, Moossa AR, Bouvet M and Hoffman RM: Development of real-time subcellular dynamic multicolor imaging of cancer cell trafficking in live mice with a variablemagnification whole-mouse imaging system. Cancer Res 66: 4208-4214, 2006.

29 Hoffman RM: Patient-derived orthotopic xenografts: better mimic of metastasis than subcutaneous xenografts. Nature Reviews Cancer 15: 451-452, 2015.

30 Murakami T, Kiyuna T, Igarashi K, Kawaguchi K, Zhang Y, Hiroshima Y, Nelson SD, Dry SM, Li Y, Yanagawa J, Russell T, Federman N, Singh A, Matsuyama R, Chishima T, Tanaka K, Endo I, Eilber FC and Hoffman RM: Tumor-targeting Salmonella typhimurium A1-R regresses an osteosarcoma in a patient-derived xenograph model resistant to a moleculartargeting drug. Oncotarget 8: 8035-8042, 2017.

31 Hoffman RM: The multiple uses of fluorescent proteins to visualize cancer in vivo. Nat Rev Cancer 5: 796-806, 2015.

32 Hayashi K, Zhao M, Yamauchi K, Yamamoto N, Tsuchiya H, Tomita $\mathrm{K}$ and Hoffman RM: Cancer metastasis directly eradicated by targeted therapy with a modified Salmonella typhimurium. J Cell Biochem 106: 992-998, 2009.
Received January 24, 2017

Revised February 23, 2017

Accepted February 24, 2017 